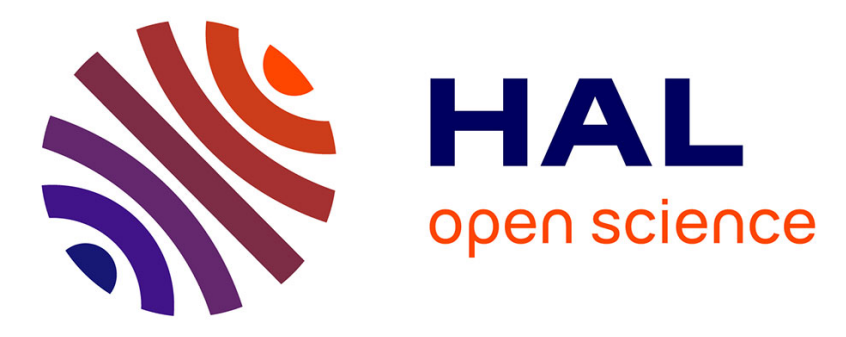

\title{
Mapping of central africa forested wetlands using remote sensing
}

J. Betbeder, V. Gond, Frédéric Frappart, N. Baghdadi, G. Briant, E. Bartholomes

\section{- To cite this version:}

J. Betbeder, V. Gond, Frédéric Frappart, N. Baghdadi, G. Briant, et al.. Mapping of central africa forested wetlands using remote sensing. IEEE Journal of Selected Topics in Applied Earth Observations and Remote Sensing, 2013, 7 (2), p. 531 - p. 542. 10.1109/JSTARS.2013.2269733 . hal00966798

\section{HAL Id: hal-00966798 https://hal.science/hal-00966798}

Submitted on 28 Mar 2014

HAL is a multi-disciplinary open access archive for the deposit and dissemination of scientific research documents, whether they are published or not. The documents may come from teaching and research institutions in France or abroad, or from public or private research centers.
L'archive ouverte pluridisciplinaire HAL, est destinée au dépôt et à la diffusion de documents scientifiques de niveau recherche, publiés ou non, émanant des établissements d'enseignement et de recherche français ou étrangers, des laboratoires publics ou privés. 


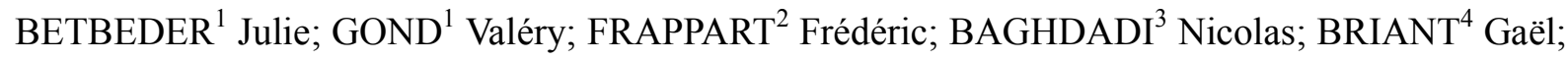
BARTHOLOME $^{5}$ Etienne

1- CIRAD, Forest ecosystems goods and services, TA-C105, F-34398 Montpellier Cedex, (France)

2- Université de Toulouse; CNRS; IRD; OMP GET; 14 Avenue Edouard Belin, 31400 Toulouse, (France)

3- IRSTEA, UMR Tetis, 34196 Montpellier (France)

4- Département des sciences géomatiques, Pavillon L.-J.-Casault, Universite Laval, Quebec, G1K 7PK (Canada)

5- Joint Research Centre, European Commission, I-21027 Ispra (Italy) 


\begin{abstract}
Wetlands represent $6 \%$ of the Earth's land cover surface. They are of crucial importance in the global water cycle and climatic dynamics. Nowadays, wetlands are the most threatened land cover type, nevertheless their spatial distribution and ecological functions are poorly documented. Despite the need for more detailed information, wetland mapping is a rarely activity. Few data are available mainly because of the complexity of obtaining good field data. We therefore propose a method based on multi sensor imagery analysis, to characterize land cover patterns of the second largest wetland area of the world (The 'Cuvette Centrale' of the Congo River basin). Time series of MODIS (Moderate Resolution Imaging Spectroradiometer) EVI (Enhanced Vegetation Index) images are used to map land cover types based their phenological differences. Flooded areas in the Congo Basin have been mapped during different seasons using L-band synthetic aperture radar (PALSAR) imagery. The associated model has been improved upon by the addition of elevation data as well as mean canopy heights acquired with LIDAR (Light Detection and Ranging) data. The result of this study is the first detailed spatial distribution of four forested wetland types within the 'Cuvette Centrale' of the Congo River basin. This study demonstrates that the spatial organization of the floodplain landscape depends on the extent of flooding. The results also show that land cover phenology is closely related to the time period of flood and solar intensity for this region, similarly to what is observed in the extensive floodplain of the Amazon basin.
\end{abstract}

Keywords: Remote sensing, large river floodplain forest, landscape, Congo River basin, PALSAR, MODIS, ICESat/GLAS 


\section{Introduction}

Wetlands and floodplains, which cover approximately $6 \%$ of the Earth's ice-free land surface (Matthews \& Fung, 1987; Organisation for Economic Cooperation and Development (OECD), 1996), have many economic uses and provide an abundance of ecological services (Frazzier, 1999; Gosselink and Mitsch, 2000). Wetlands have a substantial impact on the alteration of flooding, flow rates, sediment stabilization, water quality, and groundwater recharge and discharge (Maltby, 1991; Bullock \& Acreman, 2003). Wetlands also play a key role in biogeochemical cycles, including the methane $\left(\mathrm{CH}_{4}\right)$ and carbon dioxide $\left(\mathrm{CO}_{2}\right)$ cycles in particular (Matthews, 2000; Shindell et al., 2004), and therefore exert influence on climate dynamics (RAMSAR convention, 1971). Wetlands are reservoirs of complex biological processes (Arfi, 2002), hot spots of biodiversity (Keddy et al., 2009), and they are also crucial in the life cycle regulation of many fauna and flora species (Hey \& Philippi, 1995). Wetlands also provide habitats for fishing and hunting and may contain wood suitable for harvesting or exploitation (Callicott \& Frodeman, 2009). Despite the provision of multiple ecosystem services, wetlands appear to be the most threatened of all landscape types (Callicott \& Frodeman, 2009). The threat to wetlands is testified by the loss of half of the world's wetlands during the last century. This decrease was mainly due to anthropogenic pressure and climate change (Mitsch \& Gosselink, 2007; Murdoch et al., 2000; Maltby, 1986). International and local institutions promoted the conservation of wetlands since the RAMSAR convention ratified in 1971. The emphasis on nature conservation increased over the last twenty years (Frazzier, 1999; Convention for Biological Diversity, 1992).

Although many research efforts have attempted to characterize the large river floodplain of the Congo basin ecosystems so as to bolster their protection, the lack of knowledge regarding their spatial distribution and their ecological functions has hindered these efforts significantly (Junk \& 
Piedade, 2005). The forested wetlands within the 'Cuvette Centrale' of the Congo River basin, the second largest basin in the world after the Amazon basin, are poorly documented. Various projects at different levels of maturity proposed for example to transfer water from several tributaries of the Congo River into lake Chad (Bonifica, 1982, 1984 and 1985; Misser, 2003; Turton \& Ashton, 2004; Biggs \& Williams, 2001). These water transfers would produce substantial modifications to the hydrological regime in the 'Cuvette Centrale' and hence would cause a significant threat to the forested wetlands in the Congo River basin. The impacts of such a water transfer is also likely to be amplified by climatic change within the region (IPCC, 2007). The risk of a degradation or even the destruction of forested wetlands resulting from a significant reduction in high water levels due to either natural or anthropogenic changes is particularly important. The lack of ecological as well as hydrological information render corroborated decision making difficult.

In this respect, remote sensing (RS) offers a unique opportunity to map and describe landscape units and forest types of areas where direct access is difficult. The spectral bands provided by RS sensors allows the investigation of different aspects of these tropical swamp ecosystems. Optical data are often used to characterize types of vegetation and deforestation (Vancustsem et al., 2009; Peixoto et al. 2009; Achard et al., 2001; Wittmann et al., 2002; Huete et al., 2002), and these have also been used in tropical areas even if dense cloud cover often makes characterization difficult. Radar RS observations complement optical data because they provide valuable information even when monitoring tropical land surfaces, which often have high cloud coverage. In addition, L-band SAR sensors are very useful for the monitoring inundated wetlands (Rosenqvist et al., 1999; Frappart et al., 2005). Light Detection and Ranging (LIDAR) has also been applied in remote areas for the investigation of topography and maximum canopy height in flat areas (Lefsky et al., 2007). In 2010, Ballhorn et al. used ICESat/GLAS data (a space-borne LIDAR system) to estimate elevation and canopy height in a peat-land region of Kalimantan, Borneo. Various estimates of forests biomass were derived from these results. 
The combination of information provided by both classes of sensors allowed us to study many aspects of the tropical forest habitat, including not only its spatial distribution but also its structure and certain ecological functions and processes. Two previous studies using RS data aimed to map the wetland area within the 'Cuvette Centrale' of the Congo River basin. The first was conducted by De Grandi et al. (1998) and used a single sensor approach and JERS-1 L-band SAR images to map flooded and non-flooded forest areas. The second study, was conducted by Bwangoy et al. (2010) using a multi-sensor approach, to produce a 'wetland probability map' for the 'Cuvette Centrale' with a higher accuracy than the map created in the first study.

Though the forest types present in the 'Cuvette Centrale' have been well documented (Evrard, 1968), their spatial distributions have been poorly described due to difficulties of access to the floodplain area, lack of infrastructure and political instability. Hence, the accurate mapping of the spatial extension of the forest ecosystems within the 'Cuvette Centrale' is a strong requirement for enabling the monitoring of land cover changes related to modifications in rainfall and the associated hydrological regimes of the Congo River basin. Our objective is to document the spatial distribution and functional description of the wetland land cover types, using a multi-imagery remote sensing approach. This approach is fundamental for a continental water resources assessment for natural and anthropogenic interpretation.

\section{Material and Methods}

\subsection{Study area}

The Congo River basin harbors the second largest forest area in the world preceded only by the Amazon River basin. The study area under consideration, the 'Cuvette Centrale', is located in the center of the Congo River basin. It extends along the equator from $22^{\circ}$ longitude west to $16^{\circ}$ longitude east and from $3^{\circ}$ latitude north to $3^{\circ}$ latitude south (Fig. 1). Bwangoy et al. (2010) 
provided a map of this wetland area using a multi-sensor approach. From this study, a mask of the forested wetland was used to delineate the area of the current study (Fig. 1).

[Figure 1]

\section{Physiography}

The 'Cuvette Centrale' is surrounded by mountains and plateaus and is the remnant of a lake that occupied the area during the Tertiary geological period. It dried out as a consequence of the reduced Congo downstream riverbed through the Crystal Mountains towards the Atlantic Ocean (Robert, 1946). Sandy, lacustrine quaternary sediments cover the base of the area where forested wetlands are located (Lepersonne, 1974; Moukolo et al., 1993; Censier, 1996). The topography is almost without height differences, and the average slope is less than $7 \mathrm{~cm} / \mathrm{km}$ between Kisangani and Kinshasa (Devroey, 1957) over the last $50 \mathrm{~km}$ of the Kasai (Devroey, 1939) and over the last 450 km of the Ubangi downstream of Dongo (Yayer, 1951). Within the 'Cuvette Centrale', the Congo River and its tributaries are bordered by discontinued levees that have been covered with flooded forest (Yayer, 1951). The floodplain is not limited laterally by these levees, and floods can extend over very large areas through networks of natural channels during high water seasons.

\section{Rainfall}

The average rainfall in the 'Cuvette Centrale' ranges between 1400 and $1800 \mathrm{~mm}$. year ${ }^{-1}$, with an average of 1655 mm.year ${ }^{-1}$ in Mbandaka (0.03 N, 18 E) (Fig. 2). Potential evapotranspiration is $1280 \mathrm{~mm}$. year ${ }^{-1}$ (FAO, 2000). More than $20 \%$ of the rainfall is available for runoff, as observed in the discharge records in Brazzaville (Briquet, 1989; Shahin, 2002). Because of the topographic barrier around the 'Cuvette Centrale', a large proportion of rainfall is believed to be of local origin; it is thought to follow a closed cycle consisting of evaporated rainfall, condensation, and then again, repeated rainfall (Robert, 1946). 
[Figure 2]

\section{Hydrological regimes}

At the outlet of the 'Cuvette Centrale', only $6 \%$ of the discharge measured in Kinshasa and Brazzaville originates from the upstream part of the Congo River basin, whereas $24 \%$ comes from the 'Cuvette Centrale' itself. 23\% comes from the Kasai River sub-basin, and less than $20 \%$ comes from the Ubangi (Briquet 1993). In the 'Cuvette Centrale' between Kisangani and Mbandaka, the flow rates of the Congo River are characterized by a bimodal flooding pattern, consisting of high water in November and December, a secondary peak in April and May, low water in August and a secondary minimum in February and March. In other words, there is a 1 to 2 month time lag between flooding and rainfall seasonality (Fig. 2). Downstream of the Congo River, at Mbandaka, water is received from its two main tributaries, the Oubangi and the Kasai Rivers. The Oubangi extends its watershed over the two Congo tributaries and into the Central African Republic. The Oubangi's flow rate is characterized by high waters reaching their maximum in November while low water levels occur in March (Callède et al., 2009). The Kasai is the main tributary of the Congo River in the southern hemisphere. The watershed of the Kasai extends across the southern hemisphere into the Democratic Republic of the Congo and Angola. The Kasai reaches the Congo River at the downstream edge of the region where floodplain forest can be found. High water regimes generally occur in April, while low water regimes occur during August, although there is a small secondary high water period during December and January. In the downstream part of the river basin, waters are higher in December than in April due to the influence of the Congo River.

Within the downstream portion of the river, the waters are higher in December than in April due to the influence of the Congo's flow rate and the contribution of the Kasai tributaries that collect waters from Lake Mai-Ndombe in the equatorial domain (Devroey, 1939). The typical flood amplitude in the 'Cuvette Centrale' is between 3 and $5 \mathrm{~m}$ for the rivers (Devroey, 1957) and 
approximately $2 \mathrm{~m}$ for the floodplain (Yayer, 1951). The volume of water that is potentially stored in the 'Cuvette Centrale' under the tree canopies can equals approximately half of the annual discharge from the Oubangi to the floodplain extending from the Congo River to the Likouala-auxHerbes (Yayer, 1951).

\section{Vegetation}

The 'Cuvette Centrale' is primarily covered by forested wetland subjected to the flood pulse of the Congo River basin (Junk et.al., 1989). The vegetation in this area is poorly studied (see Evrard (1968) for a review of the botanical inventories), as is the flood height and the flood length of each vegetation types. Indeed, the geographical conditions, the lack of infrastructure and the political instability make this area very difficult to access.

Four forest types have been identified, but not spatially mapped in detail. The typology of the four forest types was establish taking into account Evrard's inventories and the typology developed by Junk et al., in 2011 for the Amazonian floodplain forest.

1) Forests subjected to relatively stable water levels (Entandrophragma palustre, Coelocaryon botryoide and Raphiales spp. palm forests);

2) Forests subjected to seasonal short lasting flood pulse of low amplitude (Guibourtia deumeusei and Oubanguia africana);

3) Non-flooded forests, characterized by higher and bigger trees (Evrard, 1968) and a more important diversity of tree species than the other groups and;

4) Forest subjected to seasonal flood pulse, located along the river (Pachystela longepedicellata and Pseudospondias microcarpa) (Léonard, 1947).

These forest types can be distinguished according to their stand structure and floristic composition. 
EVI, a "16-Day L3 Global 500 m MODIS product (MOD13A1 c5)”, is a vegetation index. Data were acquired for the period from January 2001 till December 2009, and used to map the forested wetland types within the 'Cuvette Centrale' of the Congo River basin with respect to leaf phenology (Huete et al., 2006). The values of EVI index have been derived from the multispectral measurements of the MODIS sensor onboard the NASA Terra satellite according to the following equation provided by Huete et al. (2002):

$$
E V I=\frac{G \times(\rho N I R-\rho R E D)}{(\rho N I R+C 1 \times \rho R E D-C 2 \times \rho B L U E+L)}
$$

(Eq. 1)

Where $\rho$ NIR [841-876 nm], $\rho$ RED [620-670 nm] and $\rho$ BLUE [459-479 nm] are the reflectances of near infrared, red and blue bands respectively, $\mathrm{G}$ is the gain factor, L is the canopy background adjustment (that addresses non-linear, differential NIR and red radiant transfer through a canopy) and $\mathrm{C} 1, \mathrm{C} 2$ are the coefficients of the aerosol resistance terms (which use the blue band to correct aerosol influences in the red band). The coefficients used in the MODIS-EVI algorithm are: L=1, $\mathrm{C} 1=6, \mathrm{C} 2=7.5$, and $\mathrm{G}$ (gain factor) $=2.5$. This dataset is available at http://reverb.echo.nasa.gov.

The EVI value is considered to be closely related to canopy structure and architecture. The EVI also provides improved sensitivity compared with other vegetation indices for high biomass regions, such as the tropical forest (Myneni et al., 2007; Huete et al., 2002).

To reduce atmospheric bias and remaining 'contaminated' pixels after classical atmospheric corrections (see Huete et al., 2002), time-composited EVI imagery (2000-2009) has been used. According to Pennec et al. (2010), an average for each 16-day period is calculated over the ten-year time span examined in this study. 
An unsupervised k-means classification is then performed for yearly averaged EVI imagery. To determine the optimal number of land cover classes, we used the Thorndike index (Thorndike et al., 1953):

$$
\mathrm{S}_{k}=\frac{1}{N} * \sum_{k=1}^{k_{\max }} n_{k} * \sum_{k=1}^{k_{\max }} \sum_{i=1}^{i_{\max }} \sigma_{i k}^{2}
$$

(Eq. 2)

Here, $N$ represents the total number of pixels, $\mathrm{n}_{k}$ is the number of pixels by class, $k$ is the class index varying between 1 and $\mathrm{k}_{\max }, i$ is the index of the 16-day period (from 1 to $\mathrm{i}_{\max }=23$ ), and $\sigma_{i k}^{2}$ is the variance of the class $k$ for the period $i$. The optimum number of classes is obtained using the classes that correspond to the inflection point of the $\mathrm{S}_{k}$ index.

Aerial photographs (IGN, 1961) of the Northern part of the Democratic Republic of the Congo and a topographic map of the same Northern part (IGN - Institut Géographique National 1960) with forested wetland types mapped were used to validate the EVI data. The aerial photographs represent $15000 \mathrm{~km}^{2}$ of the 'Cuvette Centrale'; their references are AE-1960-61-NA33XI-XII (from 0 to 532) and AE-1961-62-NA33V-VI (from 248 to 524).

A comparison was established between two areas of the 'Cuvette Centrale', respectively the Eala and Lukulela areas, regarding the phenology of the EVI index and ancillary data (Fig .1). The ancillary data include rainfall $(\mathrm{mm})$, light intensity (cal g/ $\mathrm{cm}^{2} /$ day) (Evrard, 1968) and the hydrology of the nearest river recorded with gauging data (Devroey, 1957; Bultot, 1971; Laraque \& Maziézoula, 1995). 


\subsection{Estimation of tree heights using GLAS/ICESat L2 Global Land Surface Altimetry data}

The Geoscience Laser Altimeter System (GLAS) instrument of the Ice, Cloud, and Land Elevation Satellite (ICESat) is a full waveform sensor consisting of a $1.064 \mu \mathrm{m}$ laser at $40 \mathrm{~Hz}$ that has been operational from 2003 to 2010 . The GLAS sensor acquired the returned energy of a footprint of $0.70 \mathrm{~m}$ and creates a waveform enabling the measurement of terrain elevation and the vertical distribution of vegetation density. This dataset includes laser footprint geo-location and reflectance as well as geodetic, instrumental, and atmospheric corrections for the range measurements. The dataset is available at http://reverb.echo.nasa.gov.

The LIDAR technique has been used to detect the topography (Blair \& Hofton, 1999) of the "footprint" and to estimate the maximum height of the canopy for each forest type. Waveform analysis enables one to approximate the maximum height of the canopy for flat terrain (Lefsky et al., 2007; Neuenschwander et al., 2008) as well as topographical elevation (Ballhorn, et al., 2010). The interpretation of these data is more complex for an area with a slope, where vegetation and ground reflectance are mixed in the signal return (Chen, 2010).

Two kinds of products have been used to study the waveform:

1) GLA01 as the raw product;

2) GLA14 which provides an approximation of beginning and end signals by fitting the complex waveform from GLA 1 into six Gaussian maximum peak distributions (Zwally et al., 2003; Harding \& Carabajal, 2005).

From these Gaussian peaks, vegetation structure and topography could be extracted. All ICESat/GLAS data available for the 'Cuvette Centrale' from February 2003 to January 2009 were procured. The GLA14 data available were converted into shape vector files to enable overlays with EVI based classifications and ICESat tracks. This makes it possible to select corresponding MODIS footprints. 
Two hundred footprints (issued from the unsupervised classification of MODIS data) were selected by EVI class to analyze the correlation between topography and spatial distribution for the different types of forested wetlands. The maximum height of the forested wetland types was determined by waveform analysis using the distance between the beginning of the signal and the centroid of the ground return (Ballhorn et al. 2010).

\subsection{Estimating inundation by ALOS PALSAR}

The Phased Array type L-band Synthetic Aperture Radar (PALSAR) sensors on board of the Lband Advanced Land Observing Satellite (ALOS) have been chosen to study the process of inundation. Six images, which were acquired on 1/25/2009, 3/15/2010, 4/27/2009, 09/07/2007, $10 / 25 / 2008$, and $12 / 13 / 2009$, have a horizontal/horizontal polarization and a $100 \mathrm{~m}$ spatial resolution at various viewing angles (from $18^{\circ}$ to $43^{\circ}$ ).

SAR imagery is sensitive to the presence of water located under the vegetation canopy since the backscattered signal is significantly increased due to the radar double-bounce returns from the water and vegetation surfaces. The ScanSAR imagery has been pre-processed with respect to radiometric calibration, incidence angle normalization and speckle reduction. The imagery has first converted into sigma nought $\left(\sigma_{0}\right)$ in $\mathrm{dB}$ (ALOS PALSAR, 2008). The angle of incidence effect on the backscattering coefficients have been corrected using the procedure developed by Baghdadi et al. (2001). The normalized backscattering coefficient is given by:

$$
\sigma_{n}^{\circ}=\frac{\sigma^{\circ}\left(\theta_{i}\right)}{F\left(\theta_{i}\right)}
$$

Here, $\sigma^{\circ}\left(\theta_{i}\right)$ represents the backscattering coefficient $(\mathrm{dB})$ at the incidence angle ${ }^{\theta_{i}}$.

In linear units, $\sigma^{\circ}\left(\theta_{i}\right)$ is given by the relation $\beta \cos ^{\alpha} \theta$ (Ulaby et al., 1982; Beauchemin et al., 1995). Thus, $\mathrm{F}(\theta)$ is of the form $\beta \cos ^{\alpha} \theta$, and the normalized backscattering coefficient $(\beta)$ is given 
as $\sigma^{\circ}\left(\theta_{i}\right) / \cos ^{\alpha} \theta_{i}$ (Baghdadi et al., 2001). For each date of acquisition, the coefficient $\alpha$ is equal to the slope of the linear relationship between $\sigma^{\circ}(\mathrm{dB})$ and $10 \log [\cos (\theta)]$, which has been established using ten homogeneous regions of interest (ROI's) chosen in the non-flooded forest and at an incidence angle between $18^{\circ}$ and $43^{\circ}$. A Lee filter (Zhenghao \& Fung, 1994) has subsequently been applied to a window of $7 * 7$ pixels to reduce speckle. Similar to EVI, an unsupervised k-means classification was performed for an optimum number of classes. This unsupervised classification was applied to a temporal series of PALSAR scenes, which represented different periods of flooding in the study area. To study the dynamics of inundation, each class was averaged.

A $\chi^{2}$-test was used to establish the relationship between an EVI class and a PALSAR class.

\section{Results}

\subsection{EVI classification for forested wetland types}

Based on the Thornlike index presented in Fig. 3, the optimum number of EVI-based forest classes has been determined using the elbow effect (Tibshirani et al., 2001). An unsupervised classification for the EVI average year was performed, and the results were clustered into four classes (Fig. 3).

\section{[Figure 3]}

The classification result is shown in Fig. 4. The class EVI-1 of forest is located mainly alongside rivers and large lakes. This class is also present in the southwestern part of the Congo River basin and northwest of Lake Tele. EVI-1 covers an area of $24000 \mathrm{~km}^{2}$. The EVI-2 class is present in the central region of the 'Cuvette Centrale' and covers $85000 \mathrm{~km}^{2}$. The EVI-3 class covers 121000 $\mathrm{km}^{2}$ and is frequently associated with the EVI-2 class. The EVI-4 class covers a smaller area (56 
$000 \mathrm{~km}^{2}$ ) and occurs near Lake Tele in the north of the 'Cuvette Centrale' along the Oubangui River as well as in the south near the lakes and tributaries of the Congo River.

[Figure 4]

The EVI classification has been compared and validated using two different datasets: the topographic map of Northern Congo (IGN, 1960) and the soil and tree elevations derived from the GLAS measurements. Thematic accuracy of the EVI vegetation map was assessed using a $\chi^{2}$ test and a contingency table according to the IGN topographic map and the spatial distributions of the EVI classes. These results are shown in Fig. 5. EVI class footprints and transitions between EVI classes have been visually photo-interpreted using aerial photographs (shape, location and map).

[Figure 5]

GLAS data allow for the acquisition of average elevations and maximum canopy heights for three EVI classes (Table 1). Class EVI-1 does not produce results due to the lack of ICESat-GLAS data for this type of forest. At least one EVI class elicits elevations significantly different from the others (ANOVA, p-value $<0.5$ ). On average, the EVI-2 class is associates with the lowest elevations and is characterized by the lowest maximum canopy height. On average, the elevation of the EVI-4 class is higher than that of the other classes and demonstrates the largest maximum canopy height.

[Table 1]

Time series analysis suggests that differences between EVI classes are not linked with phenological patterns (Fig. 6). Although the EVI classes demonstrate a similar temporal evolution, they display different magnitudes of EVI values. Each forested wetland type is characterized by a leaf phenology 
cycle with two peaks of activity during May and October separated by a decrease of leaf density in December and August. Each EVI class exhibits similar characteristics, and an EVI mean value increasing as the class type changes from EVI-1 to EVI-4 (Fig. 6). These variations are mostly based on the intensity of the greenness related to the EVI index.

[Figure 6]

\subsection{PALSAR-derived inundation classification}

The optimum number of classes has been determined using the Thornlike index. For the series of PALSAR images of the 'Cuvette Centrale', the optimum number of classes is five (Fig. 7). One class represents the borders of the image, and its value is equal to zero for each of the PALSAR images examined.

[Figure 7]

The time variations of the backscattering coefficients for each class are shown in Fig. 8. Four areas with distinct flooding patterns can be observed. The temporal dynamics of the backscattering coefficients for each class allow the characterization of each class in terms of inundation and land cover. PALSAR-1 data reveal low backscatter values associated with large annual amplitude that peaks in March/April at approximately $-12.5 \mathrm{~dB}$ and reaches a minimum of $-18 \mathrm{~dB}$ in October. PALSAR-2 data have an almost constant backscatter coefficient with values between 7.5 to $8.5 \mathrm{~dB}$, regardless of the season. PALSAR-3 data elicit the highest backscatter values, between 4.5 and 3.5 $\mathrm{dB}$. The maximum is observed at the end of the year. PALSAR-3 data have a temporal evolution close to that of PALSAR-2 between December and April and close to PALSAR-4 data between May and October.

[Figure 8] 
Fig. 9 presents the spatial distribution of the flooding area's derived from an unsupervised classification of PALSAR imagery. The PALSAR-1 class is typically located outside the 'Cuvette Centrale' and along the Oubangui River. The PALSAR-2 class is observed along the large rivers, such as the Congo River itself, and within the western portion of the 'Cuvette Centrale'. The PALSAR-3 class is located in the center and west of the Cuvette Centrale. The PALSAR-4 class is typically located in the vicinity of the PALSAR-3 class.

[Figure 9]

\subsection{Classification comparisons}

The two classifications presented above exhibit strong dependency $\left(\chi^{2}\right.$ test, $\mathrm{p}$-value $\left.<0.005\right)$. Thus, these results are combined to analyze the nature of the landscape (EVI classes) in relation to flooding status (PALSAR classes).

[Figure 10]

\section{Discussion}

The results of this study are the first to describe the spatial distribution of the forested wetland types in the 'Cuvette Centrale' of the Congo Basin, in detail. The multi-sensor approach applied, produces a better understanding of the phenology, the structure and the flooding periods of the different forest types. 


\subsection{Spatial distribution of the forested wetland}

The complementary use of three data sources permitted the classification of the different forested wetland types. The four forested wetland types identified by Evrard in 1968 were discriminated and mapped based on their leaf phenology using EVI imagery data. Each of these four forested wetland types have different greenness intensities but the same seasonality. Thus, our hypothesis is that the discrimination of forested wetland types according to the EVI index is based on the stand structure of each type. The density of the cover has also been shown to be significant, and the EVI index value was shown to be high (Huete et al., 2006). The structure is clearly identified on the stereo aerial photography and is related to the intensity of the EVI index (Pennec et al., 2011). Class EVI2 consists of sparse stands of forest canopy, whereas class EVI-4 has a closed stand forest structure composed of different understory strata. In general, a forest type with a multi-layered stratified canopy and a closed crown cover generates a greater EVI signal than a single-layered canopy with an open crown cover (Gond et al., 2011).

The map obtained for this study offers a good spatial and thematic accuracy compared to the IGN topography map from 1960. Moreover, the vegetation exhibits a marked zonation related to the flooding regime (relationship with PALSAR dataset) as the floodplain vegetation of the Amazon and Okavango basins (Parolin et al., 2010). The GLAS data permit the evaluation of the average elevation and the maximum canopy height for three forested wetlands, which is in agreement with the Evrard and Leonard (1947) indications for emergent trees of seasonal flooded forest. However we notice that it is possible that GLAS data overestimate the maximum canopy height because in the Amazon floodplain, the forests subjected to relatively stable water level reaches an average height of 15-20 meters (Scarano et al., 1997). 


\subsection{Hydrological dynamics}

Four hydrological dynamics were identified using the PALSAR multi-temporal images that can be related to the vegetation map.

In general, radar backscattering is lower for an open water body than for other surfaces. This is due to specular reflection from the water surface. This is a characteristic which permits the accurate determination of the extent of the flooding area for open water bodies, such as rivers and lakes not covered with vegetation. Moreover, the L-band has extensive higher canopy penetration depth, permitting the detection of water surfaces below the canopy. The multi-temporal use of L-band imagery allows the discrimination between forest subjected to relatively stable water level, forest subjected to seasonal flood pulse and non-flooded areas. As shown in Fig. 8, there is no overlap of the mean values with their standard deviations indicated, for each class. The PALSAR imagery in the ScanSAR mode allows us to detect flooding over large areas (i.e., from 250 to $350 \mathrm{~km}$, or three to five times the footprint of a conventional SAR scene).

Regarding PALSAR image classification, the PALSAR-1 class elicits the lowest level of backscattering and can be used to identify non-covered water surfaces (rivers and lakes). Increasing backscattering coefficients during the low water season (March/April) are likely to be the consequence of the presence of islands and vegetation species found in the river channels and the open water of the Likouala-aux-Herbes and Moanda Rivers. PALSAR-2 exhibits very low backscatter variation over a year and a relatively low mean backscattering value. This is assumed to be originating from volume as well as multiple scattering mechanisms of non-flooded forests (Martinez \& Le Toan, 2007; Evans et al., 2010). PALSAR-3 has the highest backscattering coefficient values due to the double-bounce effect of the interactions of the radar pulse with 
vegetation trunks and the underlying water surface (Hess et al., 1995; Wang et al., 1995). Because the backscattering coefficient has low temporal dynamics (less than $1.5 \mathrm{~dB}$ ), this signature can be attributed to the forest subjected to relatively stable water levels. PALSAR-4 exhibits time variations similar to those of PALSAR-2 (non-flooded forests) during low water level periods (March/April) and variations similar to those of PALSAR-3 (forest subjected to relatively stable water level) during high water level periods (October/January). This class is associated with forests subjected to seasonal short lasting flood pulse, with low amplitude ( $<5 \mathrm{~m}$, Yayer, 1951). At the end of the year, the PALSAR-4 backscatter is lower than the PALSAR-3 return, which is likely to be due to the tree density of forests subjected to seasonal flood pulse compared to the low density of forests with stable water level.

The results of this study have been partially validated using the Congo River and Oubangui water levels in the 'Cuvette Centrale'. These water levels represent the increased water levels at the end of the year (November-December) and the lower water levels in March and April from the PALSAR-4 profile (Fig. 8). In terms of the dynamics and backscattering values, these results are consistent with those recently published for forest units, including flooded and non-flooded forests, using ALOS PALSAR data for the classification of different types of tropical and temperate forests (Thiel et al., 2009; Ardila, et al., 2010; Evans et al., 2010).

The comparison of the EVI and PALSAR classifications with the IGN topographic map demonstrates agreement for the spatial units obtained. However, we must consider that the 'Cuvette Centrale' of the Congo River basin is located on the equator and is therefore located in both the southern and the northern hemispheres, which each have distinct hydrologic systems (Devroey, 1957). The PALSAR ScanSAR dataset currently available for this area only allows us to consider two seasons, the beginning and the end of the year. As a result, neither specific months nor the contribution of each tributary of the 'Cuvette Centrale' to the global inundation has been studied in 
detail. Detailed monitoring of inter-annual variation regarding the extent of flooding within this vegetation landscape is not currently accessible with ALOS radar data.

\subsection{Classifications comparisons}

We find similar forested wetland types using both approaches (PALSAR and EVI mapping ( $\chi^{2}$ test)). The spatial distribution of the EVI classes is driven by flooding status (stable water level, seasonal flood pulse, and no flooding). The EVI-4 class corresponds to the "no flooding" PALSAR class. Since this region is labeled on the topographic map as non-flooded forest, this is consistent with our results.

Given the relationship between EVI, GLAS, and PALSAR data and based on published data, we propose the following labels for EVI classes (Fig. 4):

- EVI-1 consists of forest subjected to seasonal flood pulse, located alongside rivers, as described by Evrard (1968)

- EVI-2 consists of forests subjected to stable water level, dominated by Raphiales, occuring at an average elevation of $304 \mathrm{~m}$, and with a $20 \mathrm{~m}$ maximal canopy height;

- EVI-3 consists of forests subjected to seasonal short lasting flood pulse, with low amplitude, as described by Evrard (1968), located at an average elevation of $306 \mathrm{~m}$ and with a $30 \mathrm{~m}$ maximum canopy height;

- EVI-4 consists of non-flooded forests located at an average elevation of $311 \mathrm{~m}$ and with a 40 m maximum canopy height.

To illustrate these classes, we show four field photographs (Fig. 10). 


\subsection{Vegetation dynamics}

The current study demonstrates also that in the 'Cuvette Centrale' of the Congo River basin, there is a strong relationship between high photosynthetic activity (EVI), a high level of light intensity (Evrard, 1968), a low level of flooding and a high level of rainfall. The forested wetlands of the Congo River 'Cuvette' loop through four phenological phases (two rainy and two dry seasons; Fig. 11). Without the contribution of any field measurements, we hypothesize that some species may shed their leaves during the flooding periods (December to January and July to August), as the Amazonian floodplain trees (Schöngart et al., 2002; Haugaasen \& Perez, 2005).

[Figure 11]

At the beginning of the year (February to March), the water level of the Congo River is at its minimum, and the light intensity and rainfall increase (Devroey, 1957). The EVI demonstrates a similar increase likely corresponding with the growth of the vegetation. Rainfall and light intensity are relatively stable from March to May when Congo River flooding typically occurs (maximally in May). Then, the EVI index values increase until May, when they reach the first peak of activity, and then decrease until July. Each of the other variables also decreases until the minimum light intensities occurs in July that causes consequent photosynthetic activity decrease. This period also corresponds to large rainfall causing floods in the Congo.

Beginning in August and reaching a maximum in October, there are simultaneous increases in light intensity and photosynthetic activity, rainfall, Congo and Oubangui River floods. Additionally, these parameters reach secondary peaks of activity in October.

At the end of the year, light intensity, photosynthetic activity and rainfall decrease between November and January, which is concurrent with the maximum level of the Congo River flooding (December) and the high level of the Oubangui River. This period is also marked by lower 
greenness activity.

Previous studies (Parolin et al., 2010; Schöngart, et al., 2002) have shown that the phenology of seasonal flooded forest (e.g., in várzea and igapó) is dependent on the maximum level of inundation. However, the phenology of terra firma forest in the Amazon Basin was shown to be driven by rainfall as well as light intensity (Haugaasen \& Peres, 2005). Flooded and non-flooded forests react in a similar way; the main drivers of phenology are light and rainfall for non-flooded forest, and flooding and light intensity for flooded forests. Indeed, light intensity plays a key role. It is possible that light intensity could influence the two peaks of photosynthetic activity for each forest type because low levels of light intensity and a hydric stress occur during dry periods (Farnsworth et al., 2011; Camberlin et al., 2001). Most likely many environmental parameters play key roles in the phenology of intrinsic factors related to the phylogenetic origin of the species or genus (Wright \& van Shaik, 1994).

\section{Conclusion}

This paper explores the use of a multi-sensor approach for the thematic characterization of forested wetland types within the Congo River basin and demonstrates that each type of sensor provides complementary information for the investigation of the spatial distribution, inundation and leaf phenology of forested wetland types.

The unique feature of the 'Cuvette Centrale', compared to Amazonia, is that the rainy season occurs twice per year (April-May and September-October). The spatial distribution of forested wetland types is controlled by topography and also by the time and the intensity of the submersion. Any changes in this parameter can modify the organization and the functioning of the forested wetlands. The phenology of forested wetlands is already modified from year to year according to the interannual variations of eco-climatic parameters. 
1

2

3

4

5

6

7

8

9

10

11

12

13

14

15

16

17

18

19

20

21

22

23

24

25

26

27

28

29

30

31

32

33

34

35

36

37

38

39

40

41

42

43

44

45

46

47

48

49

50

51

52

53

54

55

56

57

58

59

60

This study investigates a new area of research regarding the 'Cuvette Centrale' floodplain in the Congo River basin. With the spatial distribution and the brief functional description provided, it is now possible to investigate this large ecosystem with more details. The documentation and the study of this huge remote area are fundamental for understanding continental natural resources involved in freshwater regulation, carbon stocks and basic chemical element exchanges at the tropical atmosphere-biosphere interface.

\section{Acknowledgments}

The authors thank NASA, ESA and IRD for providing the remote sensing data. This study was supported by CIRAD funding. The authors also thank Frederique Seyler, Sylvie Gourley-Fleury, and Yves Laumonier for their help. 


\section{$\underline{\text { References }}$}

ALOS/PALSAR (2008). Level 1 product. Format description. Level 1.1/1.5, JAXA Earth Observation Research Center, Harumi, Japan.

Ardila, J.P., Tolpekin, V., Bijker, W. (2010). Angular backscatter variation in L-band ALOS ScanSAR images of tropical forest areas, IEEE Geoscience and Remote Sensing Letters, 7 (21), $821-825$

Arfi R. (2002). Processus d'édification des ressources naturelles en zones inondables tropicales. In : Orange Didier (ed.), Arfi Robert (ed.), Kuper M. (ed.), Morand Pierre (ed.), Poncet Yveline (ed.), Témé B. (préf.) Gestion intégrée des ressources naturelles en zones inondables tropicales. Paris (FRA) ; Bamako : IRD ; CNRST, p. 169-178. (Colloques et Séminaires). GIRN-ZIT : Gestion Intégrée des Ressources Naturelles en Zones Inondables Tropicales : Séminaire International, Bamako (MLI), 2000/06/20-23. ISBN 2-7099-1480-8.

Baghdadi, N., Bernier, M., Gauthier, R., \& Neeson, I. (2001). Evaluation of C-band Sar data for wetlands mapping. International Journal of remote sensing, 22(1), 71-88.

Beauchemin, M., Thomson, K., \& Edwaeds, G. (1995). Modelling forest stands with MIMICS: implications for caliration. Canadian Journal of Remote Sensing, 21, 518-526.

Biggs D. \& Williuams R. (2001). A case study of integrated water resource management in windhoek, Namibia. Proceedings of symposium "frontiers in urban water management: deadlock or hope?", Marseille 18-20 June 2001 Workshop 1: demand management practice, policy, data and technologies. IHP-V Technical documents in hydrology n 45, UNESCO - Paris, p 10-18.

Blair, J.B., \& Hofton, M.A. (1999). Modeling laser altimeter return waveforms over complex vegetation using high-resolution elevation data. Geophysical Research Letters, 26, 2509-2512.

Bonifica, (1982), (1984) and (1985): Transaqua. Bonifica S.p. A. I.R.I ITALSAT, Roma.

Briquet, J.-P. (1989). Proceedings of "Quatrièmes journées hydrologiques de l'ORSTOM à Montpellier 14-15 Sept. 1988. ORSTOM Paris - collection “Colloques et séminaires”, p 131-146. 
Briquet, J.-P. (1993). Les écoulements du Congo à Brazzaville et la spatialisation des apports. Proceedings from the conference "Grands bassins fluviaux périatlantiques: Congo, Niger, Amazone" (INSU-CNRS-ORSTOM), Paris 22-24 Nov 1993, p 27-38.

Bullock, A. \& Acreman, M. (2003). The role of wetlands in the hydrological cycle. Hydrology and Earth System Sciences, 7(3): 358-389.

Bwangoy, J-R. B., Hansen, M. C., Roy, D. P., De Grandi, G., \& Justice, C.O. (2010). Wetland mapping in the Congo Basin using optical and radar remotely sensed data and derived topographical indices. Remote Sensing of Environment, 114, 73-86.

Callède J., Boulvert Y., \& Thiebaux J.-P. (2009). Le bassin de l'Oubangui. Coll. Monographies hydrologiques, ORSTOM Paris (CD ROM).

Censier C. (1996). Caractérisation de processus d'érosion régressive par analyse sédimentologique comparée des sables du chenal et des barres du cours inférieur de l'Oubangui (République Centrafricaine, Congo, Zaïre). Proceedings of conference "L'hydrologie tropicale: géoscience el outil pour le développement”, Paris May 1995. 1AHS Publication. 238, 1996 p 289-303

Chen, Q. (2010). Retrieving vegetation height of forests and woodlands over mountainous areas in the Pacific Coast region using satellite laser altimetry. Remote Sensing of Environment, 114, 16101627.

De Grandi, G..-F., Rosenqvist, A., Mayaux, P., Rauste, Y., Kattenborn, G.., Simard, M., Saatchi, S. \& Leysen, M. (1998). Flooded Forest Mapping at Regional Scale In the Central Africa Congo River Basin: First Thematic Results Derived by ERS-1 and JERS-1 Radar Mosaics, Second Retrieval of Bio- and Geo-physical Parameters from SAR data for Land Applications, October 1998, ESTEC, The Netherlands.

Devroey E.-J. (1939). Le Kasai et son bassin hydrographique. Annales des Travaux Publics de Belgique, Bruxelles, 334 pages.

Devroey E.-J. (1957) Annuaire hydrologique du Congo belge et du Ruanda - Urundi 1956. Académie Royale des Sciences Coloniales. Bruxelles, Classe Sciences et Techniques. Memoires. in- 
$8^{\circ}$, nouvelle Série T. VII Fasc. 3469 pages.

Evans, T.L., Costa, M., Telmer, K., \& Silva, T.S.F. (2010). Using ALOS/PALSAR and RADARSAT-2 to Map Land Cover and Seasonal Inundation in the Brazilian Pantanal, IEEE Journal of Selected Topics in Applied Earth Observations and Remote Sensing, 3(4), 560-575.

Evrard, C. (1968). Recherches écologiques sur le peuplement forestier des sols hydromorphes de la Cuvette Congolaise Centrale. Bruxelles, Des presses des Ets WELLENS-PAY s.a, 1968, 295 p.

FAO (2000). FAOCLIM 2: worldwide agroclimatic database. FAO Agrometeorology Group, Rome, CD ROM.

Farnsworth, A., White, E., Williams, C., Black, E., Kniveton, R. (2011). Understanding the large scale driving mechanisms of rainfall variability over Central Africa, in C.J.R., Williams, D.R. Kniveton (eds.), African Climate and Climate Change, Advances in Global Change Research 43, Doi 10.1007/978-90-481-3842-5_5, Springer Science+Business Media B.V. 2011.

Frappart, F., Martinez, J. M., Seyler, F., León, J. G. \& Cazenave, A. (2005). Floodplain water storage in the Negro River basin estimated from microwave remote sensing of inundation area and water levels Remote Sensing of Environment, 99(4), 387-399.

Frazier, S. (1999). Ramsar Sites Overview. A Synopsis of the World's Wetlands of International Importance. Wetlands International. $58 \mathrm{pp}$.

Gond, V., Freycon, V., Molino, J.-F., Brunaux, O., Ingrassia, F., Joubert, P., Pekel, J-F., Prévost, M.F., Thierron, V., Trombe, P-J., Sabatier, D. (2011). Broad scale patterns of forest landscape in Guiana Shield rain forests, International journal of Applied Earth Observation and Geoinformations, 13, 357-367. Doi: 10.1016/j.jag.2011.01.004

Haugaasen, T. \& Peres, C. A. (2005) Tree phenology in adjacent Amazonian flooded and unflooded forests. Biotropica, 37(4), 620-630. 
Hess, L. L., Melack, J. M., Filoso, S. \& Wang, Y. (1995). Delineation of inundated area and vegetation along the Amazon floodplain with SIR-C synthetic aperture radar. IEEE Trans. Geosci. Remote Sensing, 33, 896-904.

Hey, D. L. \& Philippi, N. S. (1995). Flood reduction through wetland restoration: the upper Mississippi river basin as a case history. Restoration Ecology, 3(1), 4-17.

Hladik, A. (1978). Phenology of leaf production in rain forest of Gabon: distribution and composition of food for folivores. Page 41-72 in Montgomery G. ed. The ecology of arboreal folivores. Smithonian Institution Press. Washington, D. C.

Huete, A.R., Didan, K., Miura, T.R.E.P., Gao, X., \& Ferreira, L., G. (2002). Overview of the radiometric and biophysical performance of the MODIS vegetation indices. Remote Sensing of Environment, 83, 195-213.

IPCC. (2007). Contribution of working groups I, II and III to the fourth assessment report of the intergovernmental panel on climate change. Core writing team, Pachauri, R. K. \& Reisinger, A. (Eds.). Geneva, Switzerland, 104 pages.

Junk, W.J., Bayley, P.B., Sparks, R.E. (1989). The flood pulse concept in river-floodplain systems. Can. Spe. Publ. Fish. Aquat. Sci. 106: 110-127.

Junk, J.W., Fernandez Piedade, M.T., Schöngart, J., Cohn-Haft, M., Adeney, J.M., Wittmann, F. (2011). A classification of major Naturally-Occuring Amazonian Lowland Wetlands. Wetlands, $31,623-640$.

Keddy, P. A., Fraser, L. H., Solomeshch, A. I., Junk, W. J., Campbell, D. R., Arroyo, M. T. \& Alho, C. J. (2009). Wet and wonderful: the world's largest wetlands are conservation priorities. BioScience 59(1), 39-51.

Laraque, A., Maziézoula, B. (1995). Banque de données hydrologiques des affluents du fleuve Congo-Zaïre et informations physiographiques, rapport interne lab. HydrORSTOM, Montpellier, $250 \mathrm{p}$

Lefsky, M.A., Keller, M., Pang, Y., De Camargo, P. B., \& Hunter, M.O. (2007). Revised method 
for forest canopy height estimation from Geoscience Laser Altimeter System Waveforms, Journal of Applied Remote Sensing, 1,1-18.

Lepersonne J. (1974). Carte géologique du Zaire 1/2000000. Rep. Du Zaire, commissariat d'état aux mines, service géologique, Kinshasa.

Léonard, J. (1947): Contribution a l'étude des formations ripicoles arbustives et arborescentes de la region d'Éala, C.R. Sem. Agr. Jangambi.

Maltby, E., (1986). Waterlogged wealth: why waste the world's wet places ? , Russel Press, Nottingham, $200 \mathrm{p}$.

Maltby, E. (1991). Wetland management goals : wise use and conservation. Landscape and Urban planning, $20(1-3), 9-18$.

Martinez, J.-M. \& Le Toan, T. (2007). Mapping of flood dynamics and spatial distribution of vegetation in the Amazon floodplain using multitemporal SAR data Remote Sensing of Environment, 108(3), 209-223.

Misser F. (2003). RD Congo: economy. In: Africa South of the Sahara 2003, $22^{\text {nd }}$ edition. Europa Publ. London 1360 p.

Mitsch, W.J. \& Gosselink, J.G. (2007). Wetlands 4th ed., Wiley, Oxford, 600 p

Moukolo, N., Laraque, A., Olivry, J. C. \& Briquet, J. P. (1993). Transport en solution et en suspension par le fleuve Congo (Zaïre) et ses principaux affluents de la rive droite. Hydrological Science Journal, 38(2), 133-145.

Murdoch, P.S., Baron, J.S., Miller, T.L. (2000). Potential effects of climate change on surfacewater quality in north america. JAWRA Journal of the American Water Resources Association, 36(2), pp,347-366.

Neuenschwander, A.L., Urban, T.J., Gutierrez, R., Schutz, B.E. (2008). Characterization of ICESat/GLAS waveforms over terrestrial ecosystems: Implications for vegetation mapping, Journal of Geophysical Research, N¹13 (G02S03). 
OECD. (1996). The knowledge-based economy. Organisation for economic co-operation and Development, Paris.

Parolin, P. (2009). Submerged in darkness: adaptations to prolonged submergence by woody species of the Amazonian floodplains. Annals of Botany, 103, 359-376.

Parolin, P., Waldhoff, D. \& Zerm, M. (2010). Photochemical capacity after submersion in darkness: how Amazonian floodplain trees cope with extreme flooding. Aquatic Botany, 93: 83-88.

Parolin, P. \& Wittmann, F. (2010). Struggle in the flood: tree responses to flooding stress in four tropical floodplain systems. AoB PLANTS 2010: plq003, doi:10.1093/aobpla/plq003.

Peixoto, J. M. A., Nelson, B. W. \& Wittmann, F. (2009). Spatial and temporal dynamics of river channel migration and vegetation in central Amazonian white-water floodplains by remote-sensing techniques. Remote Sensing of Environment, 113, 2258-2266.

Pennec, A., Gond, V. \& Sabatier, D. (2011). Characterization of tropical forests phenology in French Guiana using MODIS time-series, Remote Sensing Letters, 2(4), 337-345.

RAMSAR. (1971). Convention relative aux zones humides d'importance internationale, particulièrement comme habitats des oiseaux d'eau. United Nations $n^{\circ} 14583$.

Robert M. (1946). Le Congo physique. Comité Spécial du Katanga, $3^{\text {rd }}$ Ed. Vaillant-Carmanne, Liège, 449 p Moukolo N. Laraque A., Olivry J.-C. \& Bricquet J.-P. 1993: Transport en solution et en suspension par le fleuve Congo (Zaïre) et ses principaux affluents de la rive droite. Hydrological Sciences -Journal-des Sciences Hydrologiques, 38(2,4), 133-145.

Rosenqvist, A., Forsberg, B. R., Pimentel, T. P., Rauste, Y. A., \& Richey, J. E. (1999). The use of spaceborne radar data for inundation modelling and subsequent estimations of trace gas emissions in tropical wetland areas. In IRD (Ed.), Proceedings of the Hydrological and Geochemical Processes in Large Scale River Basins Conference. Manaus, Brazil.

Scarano, F.R., Ribeiro, K.T., De Moraes, L.F.D., De Lima, H.C. (1997). Plant establishment on flooded and unflooded patches of a freshwater swamp forest in Southeastern Brazil. Journal of tropical ecology, 13(6), 793-803. 
Scarano, F.R., (1998). A comparison of dispersal germination and establishment of woody plants subjected to distinct flooding regimes in Brazilian flood-prone forests and estuarine vegetation, Ecophysiological strategies of xerophytic and amphibious plants in the neotropics. Series Oecologia Brasiliensis, 4, 177-193.

Schlüter, U.-B., Furch, B. \& Joly, C. A. (1993). Physiological and anatomical adaptations by young Astrocaryum jauari Mart. (Arecaceae) in periodically inundated biotopes of Central Amazonia. Biotropica, 25, 384-396.

Schöngart, J., Piedade, M. T. F., Ludwighausen, S., Horna, V. \& Worbes, M. (2002). Phenology and stem-growth periodicity of tree species in Amazonian floodplain forests. Journal of Tropical Ecology, 18, 581-597.

Shahin M. (2002). Hydrology and water resources of Africa. Springer Verlag, 659 p.

Thiel, C.J., Thiel, C., Schmullius, C.C. (2009). Operational Large-Area Forest Monitoring in Siberia Using ALOS PALSAR Summer Intensities and Winter Coherence, IEEE Transaction on Geoscience and remote Sensing, 47, 3993-4000.

Tibshirani, R., Walter, G., \& Hastie, T. (2001). Estimating the number of clusters in a dataset via the gap statistic, Journal of Royal Statistic Society B., 63, 411-423.

Thorndike, R., L. (1953). "Who Belong in the Family?". Psychometrika, 18.

Turton A. \& Ashton P. (2004). Southern african water cooperation - lessons from the Okavango basin. CSIR-environmentek, Pretoria 24 slides.

Ulaby, F.T., Moore,R.K., \& Fung, A.K. (1982). Microwave Remote Sensing, Active and Passive, 2, Radar Remote Sensing and Surface Scattering and Emission Theory. Addison-Wesley, advanced book program, Massachussetts, 609 pages.

Vancutsem, C., Pekel, J-F., Evrard, C., Malaisse, F., Defourny, P. (2009). Mapping and characterizing the vegetation types of the Democratic Republic of Congo using SPOT VEGETATION time series. International Journal of Applied Earth Observation and Geoinformation, 11, 62-76. 
Wang, Y., Hess, L. L., Filoso, S. \& Melack, J. M. (1995). Understanding the radar backscattering from flooded and non-flooded Amazonian forests: Results from canopy backscatter modeling. Remote Sensing of Environment, 54, 324-332.

Wittman, F., Anhuf, D., Funk, W.F. (2002). Tree species distribution and community structure of central Amazonian varzea forests by remote sensing techniques. Journal of Tropical Ecology, 18, 805-820.

Wright, S. J. \& van Schaik, C. P. (1994). Light and the phenology of tropical trees. American Naturalist, 143(1), 192-199.

Yayer J. (1951). Caractéristiques hydrographiques de l'Oubangui. Min. Colonies Bruxelles, Comité Hydrographique Congolais, 1(3), $30 \mathrm{p}$.

Zwally, H.J., R. Schutz, C. Bentley, J. Bufton, T. Herring, J. Minster, J. Spinhirne, \& R. Thomas. (2003). Updated current year. GLAS/ICESat L2 Global Land Surface Altimetry Data V018, 15 October to 18 November 2003. Boulder, CO: National Snow and Ice Data Center. Digital media. 


\section{Figures caption and Table}

\section{Figures}

Figure 1. Location of the 'Cuvette Centrale' within the Congo River basin (Africa).

Figure 2. Figure 2. The average rainfall $(\mathrm{mm})$, evapotranspiration $(\mathrm{mm})$, and average monthly components of water budget in Mbandaka (m), (sources: FAO, 2000; Devroey, 1957).

Figure 3. The Thornlike index value vs. the number of clusters for unsupervised classification of the EVI index.

Figure 4. A map of the unsupervised classification using the EVI average year. The labeling takes into account the Evrard and Junk typology, the PALSAR, the GLAS and the EVI information. The map corresponds to the EVI unsupervised classification with a masked inundated landscape (Bwangoy et al., 2010).

Figure 5. Repartition percentage of each EVI class in each IGN class; the surface area examined corresponds to approximately to $50,000 \mathrm{~km}^{2}$. IGN-1 corresponds to forests subjected to seasonal flood pulse, localised along river, IGN-2 corresponds to forests subjected to relatively stable water level, IGN-3 corresponds to forests subjected to relatively stable water level and IGN-4 corresponds to non flooded forests (IGN, 1960).

Figure 6. Annual variation of the EVI index for each forest class.

Figure 7. The Thornlike index vs. the number of clusters for the unsupervised classification of the PALSAR images.

Figure 8. Annual variation of the mean backscattering coefficient and standard deviation for each PALSAR-derived class.

Figure 9. A map of the unsupervised classification results of 6 PALSAR products.

Figure 10. Forested wetland photographs from field 


\section{Page 33 of 45}

1

2

3

4

5

6

7

8

9

10

11

12

13

14

15

16

17

18

19

20

21

22

23

24

25

26

27

28

29

30

31

32

33

34

35

36

37

38

39

40

41

42

43

44

45

46

47

48

49

50

51

52

53

54

55

56

57

58

59

60
Figure 11. The relationship between photosynthetic activity and environmental parameters (rainfall in mm, Oubangui and Congo flooding in $\mathrm{m}^{3} \cdot \mathrm{s}^{-1}$ and light intensity in cal $\mathrm{g} / \mathrm{cm}^{2} /$ day) at two stations located in the Cuvette Centrale: Eala $\left(18.28^{\circ} \mathrm{E} ; 0.0^{\circ}\right)$ and Lukolela $\left(17.18^{\circ} \mathrm{E} ; 1.08^{\circ} \mathrm{S}\right)$.

\section{$\underline{\text { Table }}$}

Table 1. EVI class structure characteristics documented with ICESAT-GLAS data. 


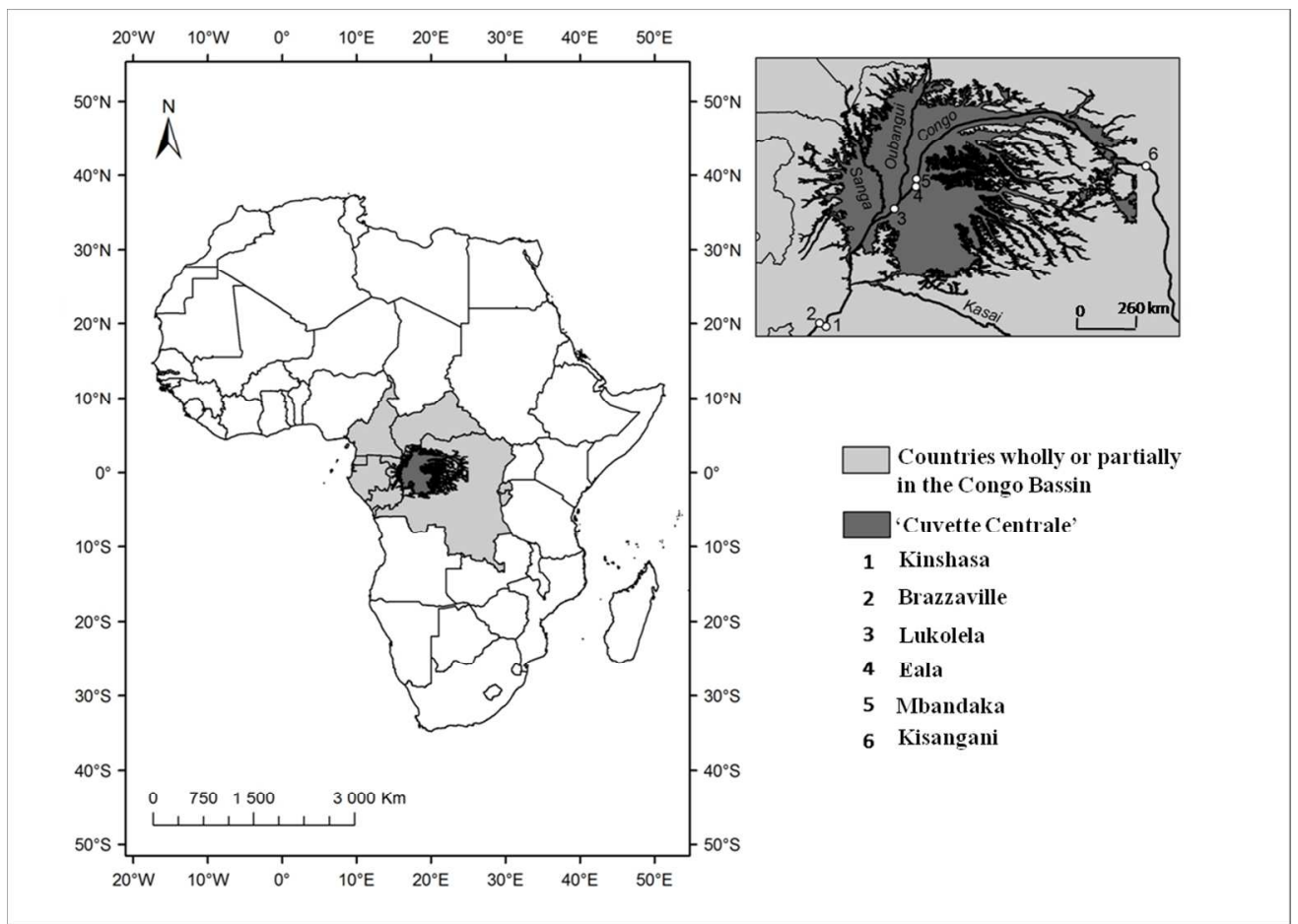

Figure 1. Location of the 'Cuvette Centrale' within the Congo River basin (Africa). 
2

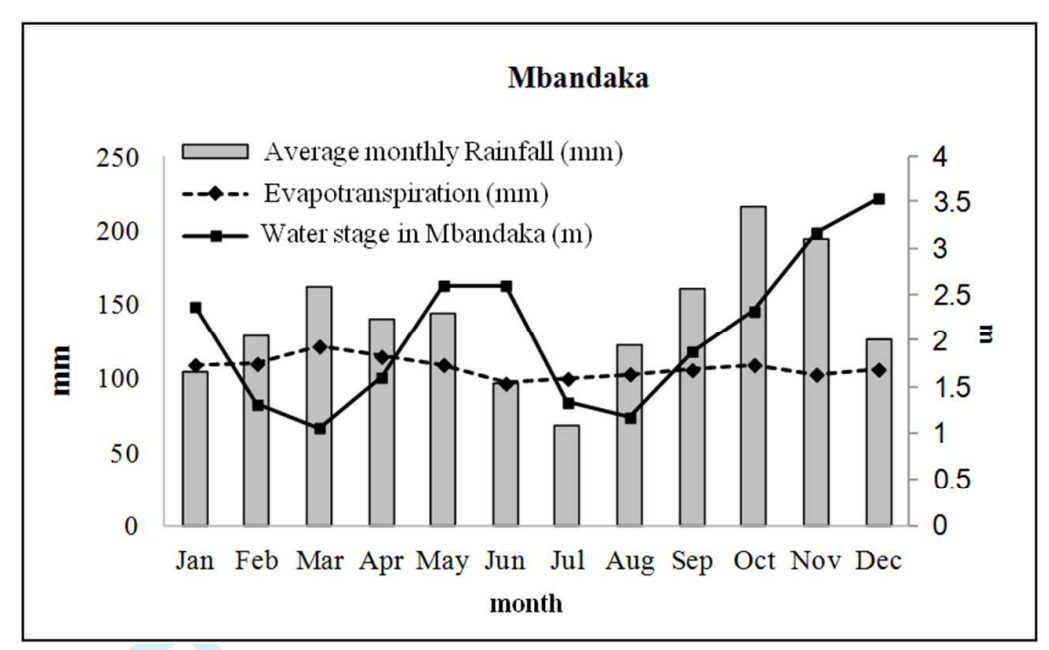

Figure 2. The average rainfall $(\mathrm{mm})$, evapotranspiration $(\mathrm{mm})$, and average monthly components of water budget in Mbandaka (m), (sources: FAO, 2000; Devroey, 1957). 
Figure 3. The Thornlike index value vs. the number of clusters for unsupervised classification of the EVI index. 
Figure 4. A map of the unsupervised classification using the EVI average year. The labeling takes into account the Evrard and Junk typology, the PALSAR, the GLAS and the EVI information. The map corresponds to the EVI unsupervised classification with a masked inundated landscape (Bwangoy et al., 2010). 
Figure 5. Repartition percentage of each EVI class in each IGN class; the surface area examined corresponds to approximately to $50,000 \mathrm{~km}^{2}$. IGN-1 corresponds to forests subjected to seasonal flood pulse, localised along river, IGN-2 corresponds to forests subjected to relatively stable water level, IGN-3 corresponds to forests subjected to relatively stable water level and IGN-4 corresponds to non flooded forests (IGN, 1960). 
Figure 6. Annual variations of average EVI (and associated standard deviation) for each forest class 
Figure 7. The Thornlike index vs. the number of clusters for the unsupervised classification of the PALSAR images. 


\section{Page 41 of 45}

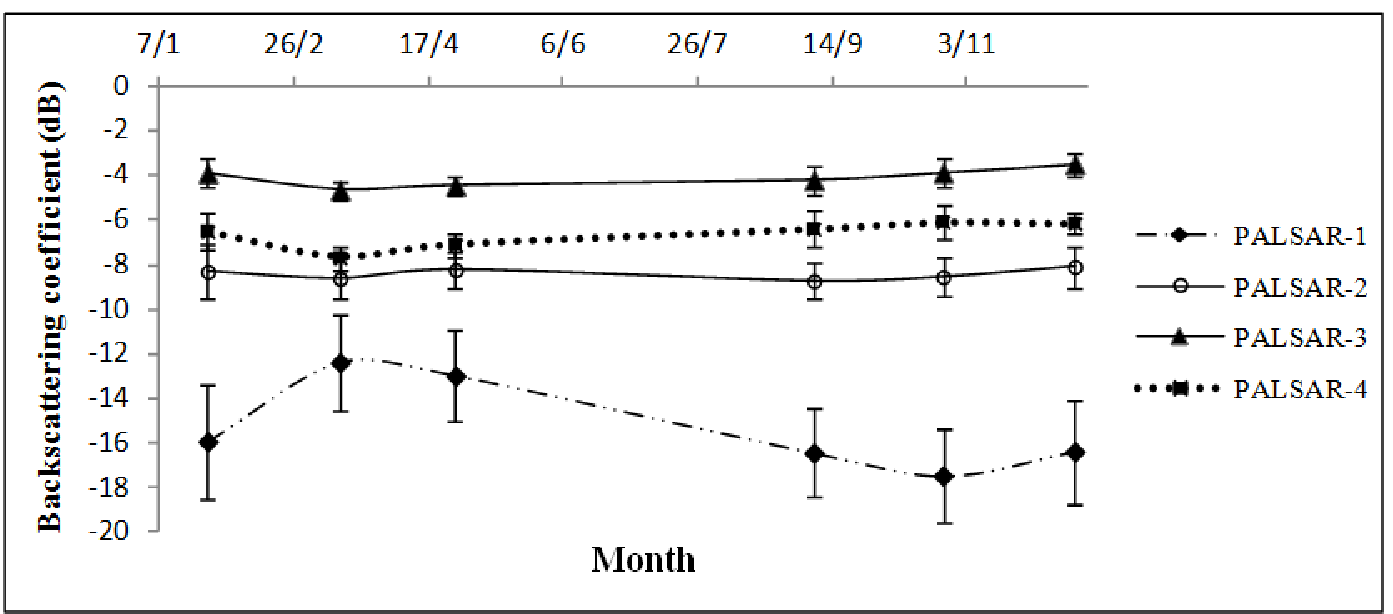

Figure 8. Annual variation of the mean backscattering coefficient and standard deviation for each PALSAR-derived class. 


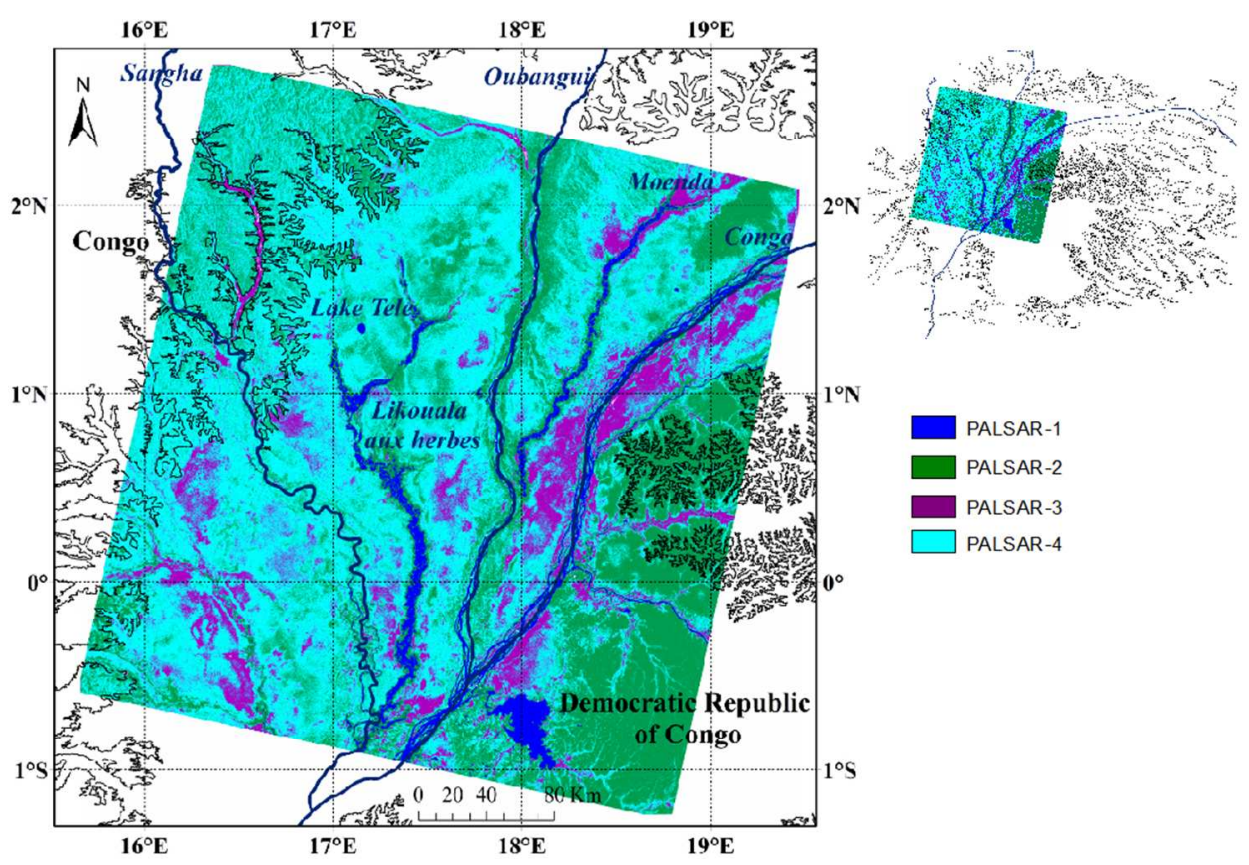

Figure 9. A map of the unsupervised classification results of 6 PALSAR products. 


\section{Page 43 of 45}

\begin{tabular}{|l|c|}
\hline \multicolumn{1}{|c|}{ Class } & Field Photographys \\
\hline $\begin{array}{l}\text { EVI 1 : forests subjected to seasonal flood } \\
\text { pulse, located alongside rivers }\end{array}$ & \\
\hline $\begin{array}{l}\text { EVI 2 : forests subjected to stable water } \\
\text { level }\end{array}$ & \\
\hline $\begin{array}{l}\text { EVI 3 : forests subjected to seasonal short } \\
\text { lasting flood pulse, with low amplitude }\end{array}$ & \\
\hline EVI 4 : non-flooded forests & \\
\hline
\end{tabular}

Figure 10. Forested wetland photographs from field 


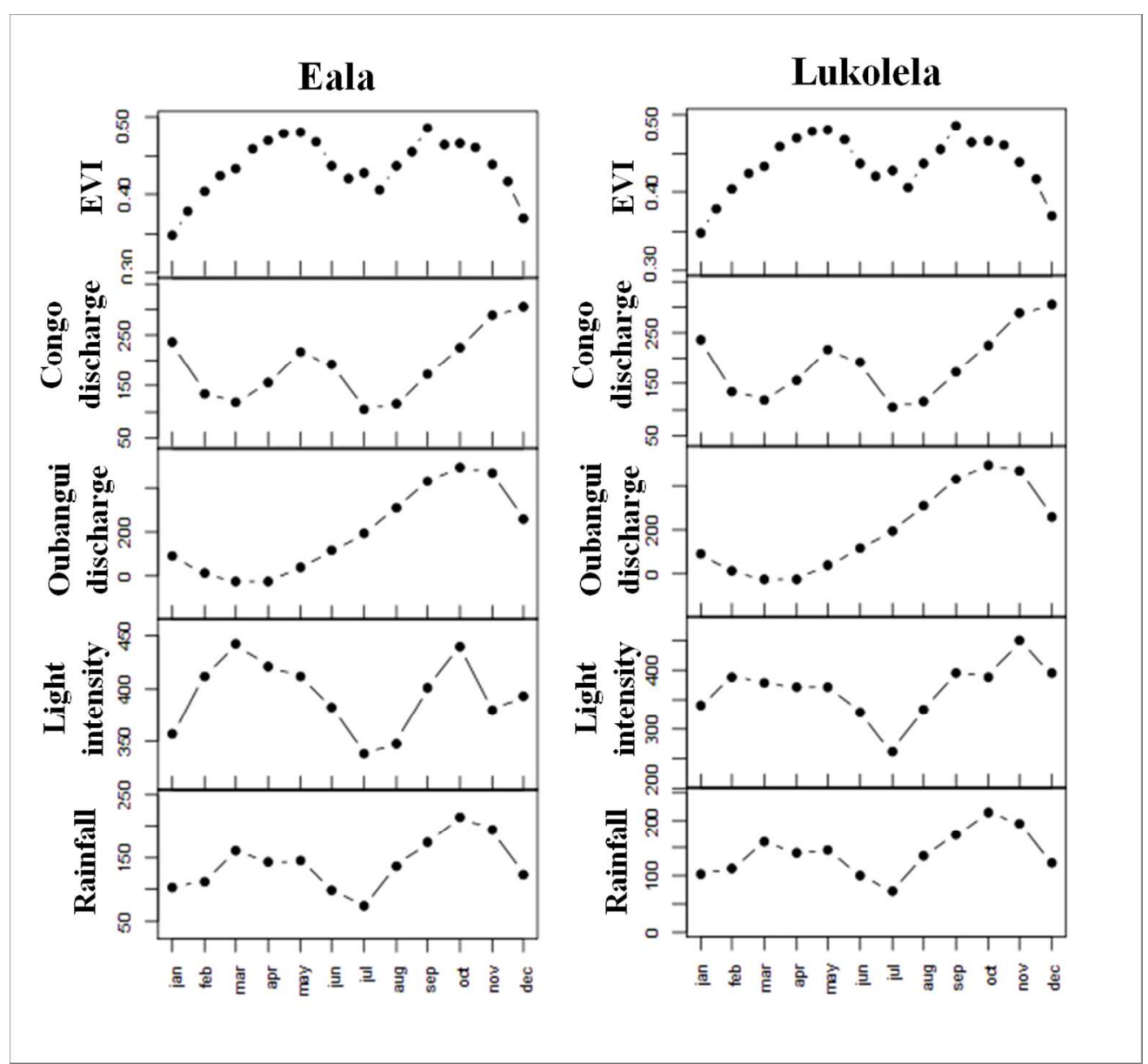

Figure 11. The relationship between photosynthetic activity and environmental parameters (rainfall in mm, Oubangui and Congo flooding in $\mathrm{m} 3 . \mathrm{s}-1$ and light intensity in cal $\mathrm{g} / \mathrm{cm}^{2} /$ day) at two stations located in the Cuvette Centrale: Eala $\left(18.28^{\circ} \mathrm{E} ; 0.0^{\circ}\right)$ and Lukolela $\left(17.18^{\circ} \mathrm{E} ; 1.08^{\circ} \mathrm{S}\right)$. 


\section{Page 45 of 45}

1

2

3

4

5

6

7

8

9

10

11

12

13

14

15

16

17

18

19

20

21

22

23

24

25

26

27

28

29

30

31

32

33

34

35

36

37

38

39

40

41

42

43

44

45

46

47

48

49

50

51

52

53

54

55

56

57

58

59

60

\begin{tabular}{|c|c|c|c|c|}
\hline \multirow[t]{2}{*}{ Class } & \multirow[t]{2}{*}{ Surface $\left(\mathrm{km}^{2}\right)$} & \multirow{2}{*}{$\begin{array}{l}\text { Average } \\
\text { elevation } \\
\text { (m) }\end{array}$} & \multicolumn{2}{|c|}{$\begin{array}{l}\text { Canopy maximum Height } \\
\text { (m) }\end{array}$} \\
\hline & & & Means & Std \\
\hline EVI-1 & 24000 & No Data & No Data & No Data \\
\hline EVI-2 & 85000 & 304 & 20 & 4.04 \\
\hline EVI-3 & 121000 & 306 & 30 & 4.8 \\
\hline EVI-4 & 56000 & 311 & 41 & 3.7 \\
\hline
\end{tabular}

Table 1. EVI class structure characteristics documented with ICESAT-GLAS data. 